Article

\title{
Sociocultural Mechanisms Concerning Cropping Systems in Mountain Agriculture: A Case Study of the Eastern Slopes of Tanzania's Uluguru Mountains
}

\author{
Yuko Yamane *(D) and Kasumi Ito \\ International Cooperation Center for Agricultural Education, Nagoya University, Furo-cho, Chikusa-ku, \\ Nagoya 464-8601, Japan; kasumito@agr.nagoya-u.ac.jp \\ * Correspondence: yamane@agr.nagoya-u.ac.jp
}

Received: 1 July 2020; Accepted: 21 August 2020; Published: 27 August 2020

\begin{abstract}
In agricultural science, the establishment of a given cropping system in mountainous areas is often understood from the relationship between differences of altitude-specific, agroecological conditions and crop cultivation characteristics. However, social factors can also play a role. We aimed to clarify how the cropping system is maintained through examining sociocultural factors, specifically land tenure and marriage systems, in an agricultural community in rural mountainous Africa. Several surveys based on participatory observation accompanied by home stays were conducted to determine people who participated in cropping systems and to understand which social system maintained the cropping system. We found that around 70\% of target households in Kiboguwa village cultivated three staple crops (maize, cassava and rice) using the same cropping system and almost no farmers outside the village used the village's sloped fields, meaning that the villagers maintained the cropping system. Households acquired nearby sloped fields by various means such as inheriting land through maternal lineage of household heads or wives. We observed virilocal and uxorilocal residence at similar degrees-and if either the husband or wife was from outside the village, that household would also have fields outside the village. However, nearly $80 \%$ of marriages were intravillage and villagers predominantly used fields located within the village limits regardless of the residence type, which helped maintain the cropping system.
\end{abstract}

Keywords: cropping system; land tenure; maternal clan; marriage system; sociocultural factors

\section{Introduction}

Subsistence farming in tropical developing countries is related to the whole life of the farmer-including his/her societal norms and customs [1,2]. When a certain crop cultivation system is observed in this type of agriculture, it has generally been established not only by environmental, but also social factors [3,4]. Due to the rapid population growth in developing countries and regions including Africa, problems such as land deterioration and shortage of cultivated land are becoming more serious and support is considered necessary to properly address the problems [5]. However, as a result of rural development assistance or agricultural technical cooperation that has been carried out through official development assistance (ODA) centered on the agricultural field, attempts have been made to centrally invest resources in developed countries as models [6]. Although the support provided technologies and varieties in south east Asia mainly for use by large-scale farmers and improved crop productivity, problems occurred such as widening economic disparities and the disappearance of reciprocal relationships in rural societies [7]. In areas where traditional tropical agriculture is practiced, modernization is often not progressing. Even if the aim is to improve economic rationality and productivity, it will be necessary to provide support according to the actual situation [8,9]. Therefore, 
it is essential to clarify how social factors are related to agriculture in order to consider support that is suitable to the region.

In agricultural science, the establishment of a given cropping system in mountainous areas is often understood from the relationship between differences of altitude-specific, agroecological conditions and crop cultivation characteristics [10-12]. Located on the eastern slopes of the Uluguru Mountains in Tanzania, Kiboguwa village lies at an altitude of 600-1400 m above sea level. Villagers cultivate various crops on the slopes using the elevation difference to their advantage. Fields are divided into two types of cultivation sites: home gardens, where mainly commercial crops such as bananas and spices are planted and sloped fields, where staple food crops such as maize, cassava and rice, which are annual crops, are cultivated [13]. There are certain cultivation patterns of these three staple food crops on the sloped field; the crops to be cultivated were determined to some extent based on altitude and cropping time [14]. The "cropping system" refers to the concept of rationally arranging crops and consists of the combination of a cropping sequence (temporal arrangement) and cropping style (spatial arrangement) [15]. Therefore, because farmers cultivate these three crops based on altitude and season, it can be said that a cropping system exists in this area.

This study aims to clarify how the cropping system used in mountainous agriculture in Kiboguwa village, Tanzania, was established and is maintained in relation to social factors such as local land tenure and the marital system. Specifically, we will clarify landholding practices relating to the acquisition of fields in terms of distribution of land held by maternal clans and how marriages are used to maintain land holdings. This examination will elucidate how these somewhat invisible social characteristics are related to the visible features of agriculture practiced in an area.

\section{Study Area}

\subsection{Luguru Society and Land Tenure Practices}

Uluguru Mountain is located about $200 \mathrm{~km}$ inland from Dar es Salaam, the largest city in Tanzania facing the Indian Ocean and measures $55 \mathrm{~km}$ North-South and $30 \mathrm{~km}$ East-West (Figure 1). The people living on the mountain and in the surrounding areas are known as the Luguru and are engaged in agriculture. The Luguru originate from the Bantu peoples who migrated from northern and southern Tanzania about 300-400 years ago in search of new lands [16]. They have a matriarchal society with more than 50 maternal clans [17]. Marriage between members of the same maternal clan is prohibited [17].

The Luguru have more than 800 maternal lineages, which are blood-related groups smaller than clans and represent units of land ownership [17]. According to the Luguru customs, all maternal lineage members, regardless of gender, have the right to use the lineage's land and the lineage head chief plays a role in allocating the land [17,18]. Additionally, the right to dispose of land does not belong to the individual; the decision to sell land is made in consultation with other members of the lineage [19].

To use the land derived from the maternal lineage under the right of use, it is advantageous for a family to live on that land, because then a woman's children can use the land with no disputes, even after she dies. In contrast, if a family lives on the land of the father's lineage, the child is considered the "lineage's grandchild." The land belonging to the father's lineage can be used by the children only while the father is alive, but after his death the land is reallocated by the lineage head. The Luguru consider that land should be returned to the lineage that holds ownership, which is disadvantageous for any family not living on land passed down through the maternal line [17]. 


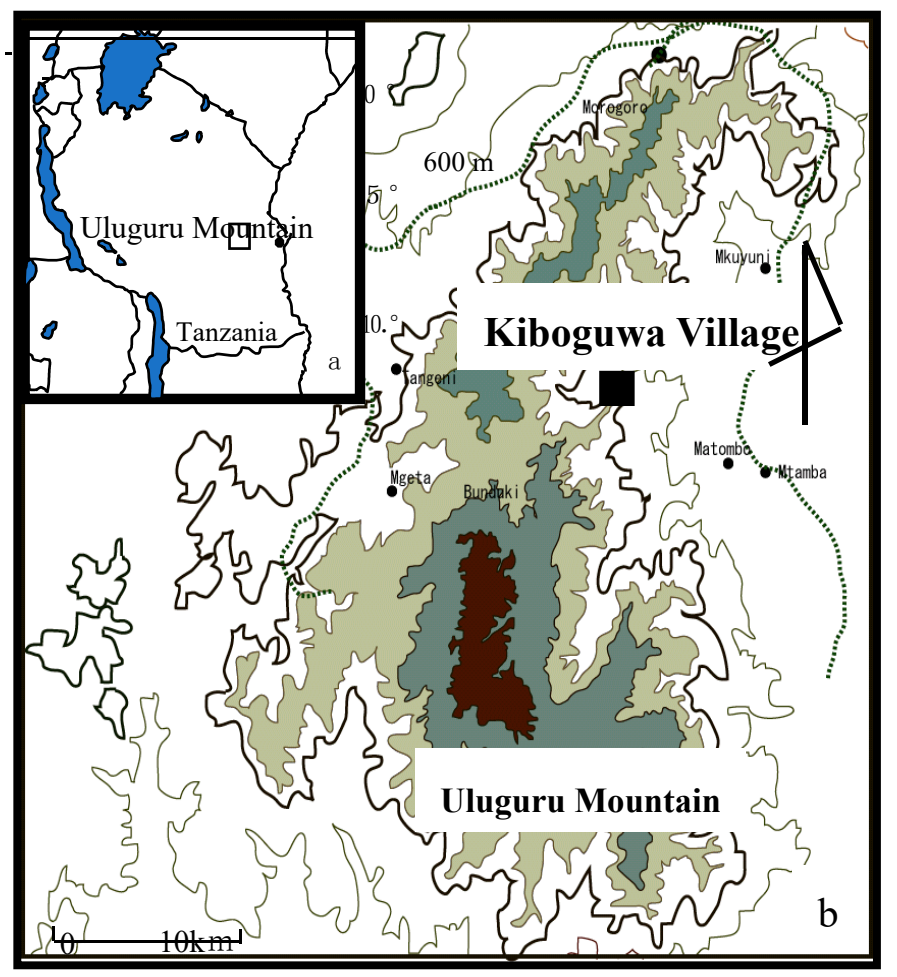

Figure 1. (a) Location of Uluguru Mountain in Tanzania; (b) location of Kiboguwa village on Uluguru Mountain.

\subsection{Kiboguwa Village Overview}

Villages located on the eastern slopes of the Uluguru Mountains are scattered at an altitude of $300-1500 \mathrm{~m}$. The center of Kiboguwa village is around $800 \mathrm{~m}$ above sea level. The terrain is complex, with many ridges running through the village. The largest ridge extends straight to the northeast, dividing the village in two and the northwest side of this ridge reaches an altitude of $1400 \mathrm{~m}$, which is the highest in the village. On the southeast side, there is a steep, cliff-like slope about 1100-m-high with a base about $800 \mathrm{~m}$. A relatively gentle downward slope continues from the bottom of the cliff to the Buha river, which corresponds to the village's lowest elevation. Villagers say that the mountainous area was once covered with forests, but at present, almost nothing remains.

The population of Kiboguwa was 1402 as of the 2002 census. The village comprises seven village wards: Kiseneke, Changa, Ludewa, Mungi, Nvure, Kirambaji A and Kirambaji B (Figure 1b). Kiseneke is situated along the ridge extending to the northeast, and its altitude is $650 \mathrm{~m}$ at the lowest point and $1400 \mathrm{~m}$ at the highest point. Changa, located in the center of Kiboguwa, is adjacent to Kiseneke, and part of it extends to the ridge that divides the village ward, extending 700-1100 $\mathrm{m}$ from sea level. Ludewa and Mungi face the Buha river and are located at a lower elevation than the previous two village wards. Mungi is also located at the same altitude and is adjacent to the nearby Tawa villages located in the eastern part about $5 \mathrm{~km}$ from the center of Kiboguwa, and Kiseneke is adjacent to the Kifuru villages.

\subsection{Cultivation of Home Gardens versus Sloped Fields}

Almost the entire slope of the village is used as cultivated land, which is classified roughly into two types: home gardens and sloped fields. A home garden (Ditualala in the Kiruguru language) constitutes a garden field next to one's home. Sloped fields (Kumgunda) spread out beyond the home gardens and are used for different forms of cultivation.

The home gardens are distributed over a wide altitudinal range on the village's mountain slopes. The lowest home garden is located at $650 \mathrm{~m}$ in Ludewa and the highest at $1220 \mathrm{~m}$ in Kiseneke. 
Many kinds of crops are grown in home gardens: 52 crops have been confirmed on the many 43 households [14]. Many tree varieties are included, such as jackfruit, mango, clove, cinnamon, breadfruit, coco palm and eucalyptus [15]. Home garden crops are often sold commercially in addition to spice crops, such as cinnamon, cardamom and cloves. Bananas are also grown in many households as commercial crops and for self-consumption [14].

In contrast, sloped fields have few perennial crops such as bananas. Three main crops, maize, cassava and rice, which are the staple food crops for subsistence farming, are cultivated on the sloped fields. Yams and kidney beans are sometimes mixed in with these crops. The village's farming season occurs twice per year: maize cultivation preparation (slash and burn) and the rice harvest coincide from early July to August and maize harvesting and preparation for rice cultivation (slash and burn and plowing) occur from mid-December to January (Figure 2). Maize is sown without plowing beforehand, and the grass is cut and burned before sowing. After the grass is burned, weeding is performed twice, but the soil is cultivated by the first weeding and gathered to sow the maize seedlings. For rice crops, the soil is cultivated using a hoe after burning and before sowing, which is the most labor-intensive cultivation of these staple foods. Cassava is often mixed with rice and is planted at the same time during the first year. After the second year and following the rice harvest, the field is used only for cassava.

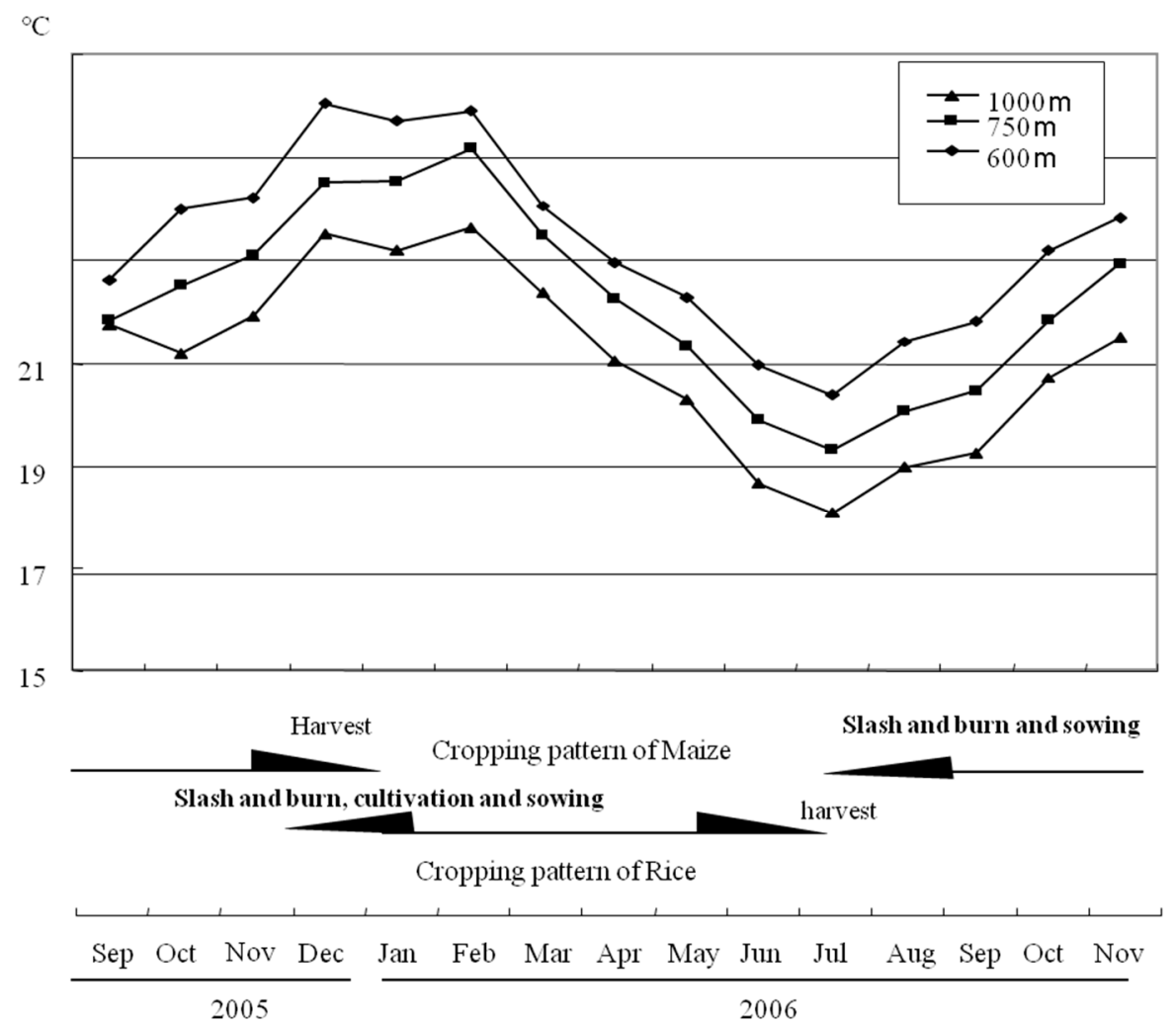

Figure 2. Relationship between annual temperature variation and cropping patterns of maize and rice at three different altitudes.

\subsection{Crops Consumed in the Village}

Nine types of staple food crops are cultivated in the village, but only maize, rice and cassava are cultivated in the sloped fields. The total annual consumption of these staple food crops, such as maize, rice, cassava, banana, sweet potato, yam, bread fruit, sorghum and taro, accounted for about $60 \%$ of the total number of meals of farmers in Kiboguwa, and they were observed to be the main food source [14]. The consumption patterns of these crops were similar among households located in different village wards [14]. 


\section{Materials and Methods}

The author, Yamane, stayed at a farmer's home in Kiboguwa for a total of 12 months from July to October 2004, June to September 2005, December 2005, December 2006 to January 2007 and June 2008. The purpose was to observe daily life and understand the relationship between usual dietary patterns and agricultural patterns. The following research was conducted while observing the farmer's daily life which was centered around agriculture. In this paper, we targeted four village ward sites: Kiseneke, Changa, Ludewa and Mungi.

Surveys were conducted to clarify the following: (1) who farms the sloped fields and (2) which social system is used to maintain the cropping system. The specific survey method and contents are described below for each item.

\subsection{Clarifying Participation in the Cropping System}

Two types of surveys were implemented. One was used to identify the cultivators and their settlements on the sloped fields where maize and rice were cultivated and the other to identify the cultivated land locations for households in each of the four village wards.

\subsubsection{Identification of Cultivators on Sloped Fields}

In January 2007, photographs were taken of five sites cultivated with maize and two sites cultivated with rice in Kiboguwa. In Figure 3, all sloped fields are identified and numbered. The cultivators from the numbered fields were identified by asking multiple neighbors surrounding each site.

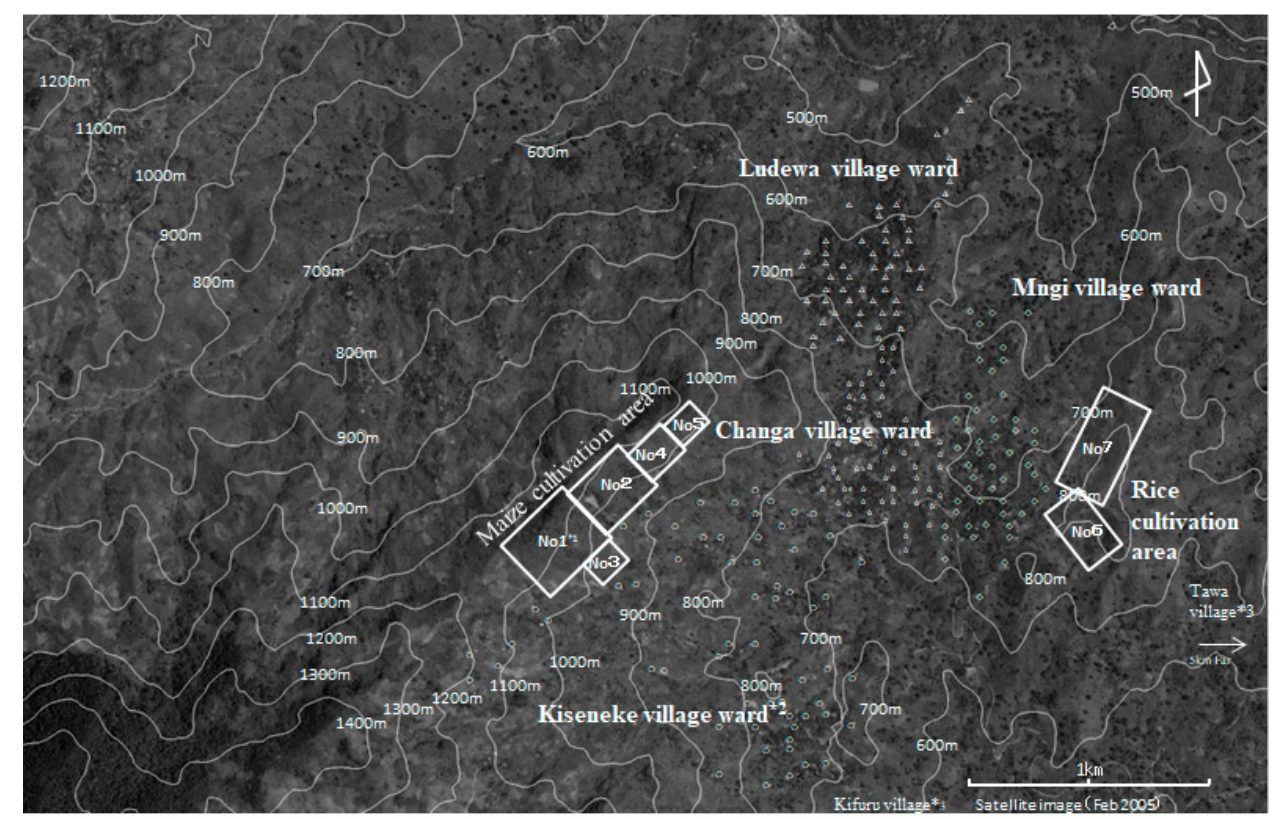

Figure 3. Distribution of sloped fields and households in Kiboguwa where cultivators were identified on maize- and rice-cultivated land. ${ }^{*} 1$ : Numbers 1 to 5 are located on the sloped field where maize is cultivated and Numbers 6 and 7 are located on the sloped field where rice is cultivated. The range of photographs that identify the cultivators of each sloped field is shown schematically. ${ }^{*}$ - distribution of 4 village wards and the distribution range of households in each of the 4 village wards. *3-direction and location of neighboring villages Kifuru and Tawa.

\subsubsection{Identification of Household Head and Household Information}

All houses in the four village wards were identified and numbered using QuickBird satellite images taken in February 2005 (Figure 3). Afterward, we walked through the village wards and recorded the location information of these houses using GPS. We also recorded the heads of each village 
ward, the name and birthplace of each head of household, spouse's presence, spouse's birthplace and lot acquisition method. We interviewed and collected information on almost all houses in the four village wards to obtain all clan names represented in each village ward. In addition, at least two people, including each head of the four village wards, were asked to provide type of clan and birthplace for all members of their village ward. They were also asked to provide clan name and birthplace of household heads and their wives for all households. The same surveys were conducted in 2005 and 2008. In 2008, we also collected information on the clans of the heads of household and their spouses to cross-check the information.

In the village wards, a married couple and their unmarried family members often live together in one house and share in the production and consumption of food. In this paper, we consider the people who live in one house to be a household.

\subsubsection{Identification of Households' Arable Lands}

In January 2007, we conducted a questionnaire survey with 80 households (out of 254) in four village wards: 17 households in Kiseneke, 23 in Changa, 18 in Mungi and 22 in Ludewa. These village wards were selected due to their distance from the author's homestay, and because it was difficult to gather information from the other three village wards. The questionnaire collected data about: (1) the place name of the household's arable land for maize, rice and cassava cultivation and (2) how each field was obtained. We visited each house and interviewed the head of household. In addition, for these 80 households, clan names and birthplaces of both household heads and their partners, who were also interviewed, were collected using the same questionnaire. These data were cross-checked against the information obtained in 2005 by the survey mentioned in Section 3.1.2.

3.1.4. Making a Map of Place Names and Distribution Diagram of Arable Lands Cultivated by Members of Three Large Clans and Small Clans

We aggregated the place names of the cultivated land and specified their locations in the satellite image in order to create a map of the place names. We asked a few informants in each village to plot the place name on the satellite image while checking the location indicated by that place name. When we could not determine the location of a place, we used GPS and went directly to the site to identify the location. Following this process, the arable lands cultivated by the 80 households investigated in Section 3.1.3 were plotted on the map based on the place names. In addition, a diagram showing the distribution of the cultivated land for each clan was created using questionnaire data.

\subsection{Clarifying How the Social System Is Related to Maintaining the Cropping System}

We collected information on residents' clan membership and conducted surveys mainly by interviewing several informants living in Kiboguwa, primarily lineage heads, to clarify how clan fields were distributed in the village.

In 2008, we conducted a survey to identify the land managed by head of the Kanoga lineage of the Ming clan. This clan was most common in Kiboguwa in 2008. The land used by lineage members as sloped fields was identified by visiting the locations given by survey respondents. The tracking data around the sloped field were obtained with GPS and were marked on the satellite images taken in 2005 (see Figure 3).

\section{Results}

\subsection{Identification of Cultivators of Sloped Fields}

Maize was cultivated in the higher-altitude areas of Kiseneke and Changa, and rice was cultivated in the lower-altitude areas of Mungi and Kiseneke. Since cassava is planted at an altitude between that required for maize and rice, planting was observed in all four village wards. The farmers who carry out this cropping system were identified, and details are presented in the following sections. 


\subsubsection{Maize Fields}

A total of 27 sloped fields were confirmed from the aforementioned photographs taken of the five maize cultivation sites (Figure 3). The cultivator who farmed each sloped field was identified and their residence was confirmed. We found that cultivators included people from all four village wards, but no cultivators from outside Kiboguwa farmed the maize sloped fields.

The No. 1 block located in Kiseneke has the highest altitude in the village (nearly $1300 \mathrm{~m}$ ) and is cultivated by residents from Kiseneke, as well as from Changa and Mungi, which are farther away. The block is far from the center of the village and is accessed by climbing a steep slope, which takes over $30 \mathrm{~min}$. For some households in Mungi, a one-way trip can take more than one hour. It is uncommon for people to build temporary huts, so they travel back and forth between their settlements and the sloped fields every day. This occurs even during the two prosperous seasons, from November to January and July to August (Figure 2) when the maize and rice cultivation periods overlap, which means they travel two to three hours every day.

\subsubsection{Rice Fields}

Rice was mainly cultivated on the slopes in Mungi, which is located in the low-altitude zone. Photographs of the two rice field sites on the slopes of Mungi confirmed the presence of 11 cultivated fields in the first site and 10 cultivated fields in the second site (Figure 3). Six farmers from Mungi, three from Changa and two from Kiseneke had fields in the first site and two farmers from Kiseneke, one from Changa and four from Mungi had fields in the second site. These cultivators were all living in Kiboguwa. Residents of another village cultivated the remaining three out of 21 rice fields: two from Kihuru village, which is adjacent to Kiboguwa and one from Tawa village, which is more than $5 \mathrm{~km}$ away. Of the 21 sloped rice fields, 18 (85.7\%) were cultivated by the Kiboguwa villagers. Therefore, most sloped rice fields were also thought to be used by residents in Kiboguwa.

\subsection{Location of Staple Food Crops Cultivated by Households in Four Village Wards}

We found few cultivators from outside the village using the sloped fields for either maize or rice, which indicates that the cropping system of staple foods used in the village is managed by its residents. However, it was also possible that households in the four village wards cultivated lands outside the village in addition to the village's sloped fields. To help clarify how social mechanisms promote the use of the cropping system and how maize and rice fields are distributed on the village's arable land, we considered it necessary to clarify the rules for using the sloped fields (e.g., inheritance or other). Therefore, we asked the households in the four village wards to indicate all the cultivated lands where they grow maize, rice and cassava to investigate where they were distributed.

More than $70 \%$ ( 58 households) of the 80 households in the four surveyed village wards cultivated maize, rice and cassava. Plot locations of these crops were mostly distributed in the four village wards and rarely outside the wards or the village. Inside Kiboguwa, maize was cultivated in 65 plots, 53 of which were sloped fields ( $81.5 \%$ ), and rice was cultivated in 94 plots, 78 of which were sloped fields (83.0\%). Cassava was cultivated in 78 plots, 67 of which were sloped fields $(85.9 \%)$ (Table 1$)$. 
Table 1. Locations and fields of three staple food crops cultivated by households living in four village wards.

\begin{tabular}{|c|c|c|c|c|c|c|c|c|c|c|}
\hline a. Maize * & & & & & & & & & & \\
\hline & & & & Resid & dence Village $V$ & Vard & & & & \\
\hline & Kiseneke & & Changa & & Mungi & & Ludewa & & Total & \\
\hline & (Household) & & (Household) & & (Household) & & (Household) & & (Household) & \\
\hline & 17 & & 23 & & 18 & & 22 & & 80 & \\
\hline Non-cultivating household ** & 1 & & 3 & & 4 & & 14 & & 22 & \\
\hline Location of sloped fields & (Fields) & $(\%)$ & (Fields) & $(\%)$ & (Fields) & $(\%)$ & (Fields) & $(\%)$ & (Fields) & $(\%)$ \\
\hline Kiseneke & 16 & 88.9 & 9 & 42.9 & 11 & 73.3 & 4 & 40.0 & 40 & 62.5 \\
\hline Changa & 0 & 0.0 & 6 & 28.6 & 2 & 13.3 & 3 & 30.0 & 11 & 17.2 \\
\hline Mungi & 0 & 0.0 & 0 & 0.0 & 0 & 0.0 & 0 & 0.0 & 0 & 0.0 \\
\hline Ludewa & 0 & 0.0 & 0 & 0.0 & 1 & 6.7 & 0 & 0.0 & 1 & 1.6 \\
\hline Other village ward & 1 & 5.6 & 3 & 14.3 & 1 & 6.7 & 0 & 0.0 & 5 & 7.8 \\
\hline Other village & 1 & 5.6 & 1 & 4.8 & 0 & 0.0 & 2 & 20.0 & 4 & 6.3 \\
\hline Unknown & 0 & 0.0 & 2 & 9.5 & 0 & 0.0 & 1 & 10.0 & 3 & 4.7 \\
\hline Total & 18 & 100.0 & 21 & 100.0 & 15 & 100.0 & 10 & 100.0 & 64 & 100.0 \\
\hline \multicolumn{11}{|l|}{ b. Rice } \\
\hline \multicolumn{11}{|c|}{ Residence village ward } \\
\hline & Kiseneke & & Changa & & Mungi & & Ludewa & & Total & \\
\hline & (Household) & & (Household) & & (Household) & & (Household) & & (Household) & \\
\hline & 17 & & 23 & & 18 & & 22 & & 80 & \\
\hline Non-cultivating household ** & 0 & & 0 & & 1 & & 0 & & 1 & \\
\hline Location of sloped fields & (Fields) & $(\%)$ & (Fields) & $(\%)$ & (Fields) & $(\%)$ & (Fields) & $(\%)$ & (Fields) & $(\%)$ \\
\hline Kiseneke & 8 & 50.0 & 3 & 12.5 & 4 & 18.2 & 2 & 6.9 & 17 & 18.7 \\
\hline Changa & 1 & 6.3 & 3 & 12.5 & 0 & 0.0 & 0 & 0.0 & 4 & 4.4 \\
\hline Mungi & 5 & 31.3 & 12 & 50.0 & 12 & 54.5 & 15 & 51.7 & 44 & 48.4 \\
\hline Ludewa & 0 & 0.0 & 0 & 0.0 & 5 & 22.7 & 5 & 17.2 & 10 & 11.0 \\
\hline Other village ward & 1 & 6.3 & 1 & 4.2 & 1 & 4.5 & 0 & 0.0 & 3 & 3.3 \\
\hline Other village & 1 & 6.3 & 5 & 20.8 & 0 & 0.0 & 1 & 3.4 & 7 & 7.7 \\
\hline Unknown & 0 & 0.0 & 0 & 0.0 & 0 & 0.0 & 6 & 20.7 & 6 & 6.6 \\
\hline Total & 16 & 100.0 & 24 & 100.0 & 22 & 100.0 & 29 & 100.0 & 91 & 100.0 \\
\hline \multicolumn{11}{|l|}{ c. Cassava } \\
\hline \multicolumn{11}{|c|}{ Residence village ward } \\
\hline & Kiseneke & & Changa & & Mungi & & Ludewa & & Total & \\
\hline & (Household) & & (Household) & & (Household) & & (Household) & & (Household) & \\
\hline & 17 & & 23 & & 18 & & 22 & & 80 & \\
\hline Non-cultivating household ** & 3 & & 5 & & 3 & & 0 & & 11 & \\
\hline Location of sloped fields & (Fields) & $(\%)$ & (Fields) & $(\%)$ & (Fields) & $(\%)$ & (Fields) & $(\%)$ & (Fields) & $(\%)$ \\
\hline Kiseneke & 11 & 57.9 & 5 & 27.8 & 3 & 15.8 & 0 & 0.0 & 19 & 24.4 \\
\hline Changa & 3 & 15.8 & 6 & 33.3 & 0 & 0.0 & 0 & 0.0 & 9 & 11.5 \\
\hline Mungi & 4 & 21.1 & 3 & 16.7 & 8 & 42.1 & 4 & 18.2 & 19 & 24.4 \\
\hline Ludewa & 0 & 0.0 & 1 & 5.6 & 6 & 31.6 & 8 & 36.4 & 15 & 19.2 \\
\hline Other village ward & 0 & 0.0 & 2 & 11.1 & 0 & 0.0 & 1 & 4.5 & 3 & 3.8 \\
\hline Other village & 0 & 0.0 & 1 & 5.6 & 1 & 5.3 & 2 & 9.1 & 4 & 5.1 \\
\hline Unknown & 1 & 5.3 & 0 & 0.0 & 1 & 5.3 & 7 & 31.8 & 9 & 11.5 \\
\hline Total & 19 & 100.0 & 18 & 100.0 & 19 & 100.0 & 22 & 100.0 & 78 & 100.0 \\
\hline
\end{tabular}

* data on the land where maize was cultivated ${ }^{* *}$ indicates the number of households that did not grow each crop among the target households.

\subsection{Cropping System and Land Retention on Sloped Fields}

According to Luguru tradition, the sloped fields should be used according to land tenure customs based on maternal clans. As shown in previous sections, households secure sloped fields for annual cultivation of maize and rice in high- and low-altitude areas, respectively. Our research explored whether these customs are actually followed, and the findings are described in the following section. 
How to Obtain Sloped Fields

We investigated the way 268 out of 277 cultivated plots (excluding home gardens) that are managed by 80 households were obtained, as well as the inheritance rules of the cropping system from the perspective of land ownership. In all village wards, most plots (89.32.1\%) were sloped fields on land derived from the wife's maternal clan, known as "lucolo" in Kiruguru. The next most common scheme was plots derived from the clan of the husband's mother (71.25.6\%). Sixteen plots were derived from the father's paternal clan $(5.8 \%)$, and 21 plots were derived from the wife's paternal clan $(7.6 \%)$, but this scheme was less common. Plots derived from the husband's or wife's maternal clan $(57.7 \%)$ and paternal clan (13.4\%) amounted to $71 \%$, indicating most land transfer is based on blood relationships. In contrast, 17 plots $(6.1 \%)$ were purchased and 26 plots $(9.4 \%)$ were leased.

\subsection{Distribution of Maternal Clan Land}

\subsubsection{Types of Maternal Clans in Kiboguwa Village}

The Luguru prohibit marriage between people from the same maternal clan [6]. After investigating the maternal clans of 254 heads of household and their spouses, 15 clans were confirmed in the village. Regarding maternal clans of the heads of household, three were most prevalent: Mwing (35.4\%), Menda (29.1\%) and Mbiki (13.0\%). All four village wards displayed a similar trend (Table 2a). In contrast, a small percentage of members belonged to the remaining 12 clans (22.4\%). Only 5\% belonged to the Mlari clan, which had the highest percentage of the 12. For spouses as well, the three maternal clans were represented in high percentages: Mwing (22.4\%), Menda (24.1\%) and Mbiki (8.0\%) (Table 2b). Therefore, we considered the Mwing, Menda and Mbiki to be the "large clans" and the other 12 the "small clans."

Table 2. Types of clans to which the householder and his/her spouse belonged *.

\begin{tabular}{|c|c|c|c|c|c|c|c|c|c|c|}
\hline \multicolumn{11}{|c|}{ a. Clan of Head of Household } \\
\hline \multicolumn{11}{|c|}{ Lukoro (Maternal Clan) } \\
\hline \multicolumn{3}{|c|}{4 Village Wards Total } & \multicolumn{2}{|c|}{ Kiseneke } & \multicolumn{2}{|c|}{ Changa } & \multicolumn{2}{|c|}{ Mungi } & \multicolumn{2}{|c|}{ Ludewa } \\
\hline Name of Clans & (People) & $(\%)$ & (People) & $(\%)$ & (People) & $(\%)$ & (People) & $(\%)$ & (People) & $(\%)$ \\
\hline Mwing & 90 & 35.4 & 23 & 37.7 & 34 & 37.8 & 19 & 37.3 & 14 & 26.9 \\
\hline Mwenda & 74 & 29.1 & 23 & 37.7 & 26 & 28.9 & 13 & 25.5 & 12 & 23.1 \\
\hline Mbiki & 33 & 13 & 5 & 8.2 & 14 & 15.6 & 7 & 13.7 & 7 & 13.5 \\
\hline Large clan total & 197 & 77.6 & 51 & 83.6 & 74 & 82.2 & 39 & 76.5 & 33 & 63.5 \\
\hline Mlari & 13 & 5.1 & 1 & 1.6 & 6 & 6.7 & 5 & 9.8 & 1 & 1.9 \\
\hline Mchuma & 8 & 3.1 & 0 & 0 & 0 & 0 & 2 & 3.9 & 6 & 11.5 \\
\hline Mkilwa & 6 & 2.4 & 3 & 4.9 & 2 & 2.2 & 0 & 0 & 1 & 1.9 \\
\hline Mzeru & 4 & 1.6 & 2 & 3.3 & 0 & 0 & 2 & 3.9 & 0 & 0 \\
\hline Mbunga & 6 & 2.4 & 1 & 1.6 & 1 & 1.1 & 0 & 0 & 4 & 7.7 \\
\hline Mbena & 6 & 2.4 & 1 & 1.6 & 5 & 5.6 & 0 & 0 & 0 & 0 \\
\hline Mzeguwa & 1 & 0.4 & 0 & 0 & 0 & 0 & 1 & 2 & 0 & 0 \\
\hline Mchilo & 3 & 1.2 & 0 & 0 & 2 & 2.2 & 1 & 2 & 0 & 0 \\
\hline Mnyani & 1 & 0.4 & 1 & 1.6 & 0 & 0 & 0 & 0 & 0 & 0 \\
\hline Mbuya & 1 & 0.4 & 1 & 1.6 & 0 & 0 & 0 & 0 & 0 & 0 \\
\hline Mtonga & 7 & 2.8 & 0 & 0 & 0 & 0 & 0 & 0 & 7 & 13.5 \\
\hline Mbangba & 1 & 0.4 & 0 & 0 & 0 & 0 & 1 & 2 & 0 & 0 \\
\hline Small clan total & 57 & 22.4 & 10 & 16.4 & 16 & 17.8 & 12 & 23.5 & 19 & 36.5 \\
\hline FtabUnknown & & 0 & 0 & 0 & 0 & 0 & 0 & 0 & 0 & 0 \\
\hline Total & 254 & 100 & 61 & 100 & 90 & 100 & 51 & 100 & 52 & 100 \\
\hline
\end{tabular}


Table 2. Cont.

\begin{tabular}{|c|c|c|c|c|c|c|c|c|c|c|}
\hline \multicolumn{11}{|c|}{ b. The Clan to Which the Spouse Belonged } \\
\hline \multicolumn{11}{|c|}{ Lukoro(Maternal Clan) } \\
\hline \multicolumn{3}{|c|}{4 Village Wards Total } & \multicolumn{2}{|c|}{ Kiseneke } & \multicolumn{2}{|c|}{ Changa } & \multicolumn{2}{|c|}{ Mungi } & \multicolumn{2}{|c|}{ Ludewa } \\
\hline Name of Clans & (People) & $(\%)$ & (People) & $(\%)$ & (People) & $(\%)$ & (People) & $(\%)$ & (People) & $(\%)$ \\
\hline Mwing & 53 & 22.4 & 15 & 27.8 & 24 & 30 & 5 & 9.6 & 9 & 17.6 \\
\hline Mwenda & 57 & 24.1 & 19 & 35.2 & 18 & 22.5 & 15 & 28.8 & 5 & 9.8 \\
\hline Mbiki & 19 & 8.0 & 7 & 13.0 & 8 & 10 & 0 & 0.0 & 4 & 7.8 \\
\hline Large clan total & 129 & 54.4 & 41 & 75.9 & 50 & 62.5 & 20 & 38.5 & 18 & 35.3 \\
\hline Mlari & 3 & 1.3 & 1 & 1.9 & 1 & 1.3 & 1 & 1.9 & 0 & 0.0 \\
\hline MCHuma & 6 & 2.5 & 1 & 1.9 & 0 & 0.0 & 0 & 0.0 & 5 & 9.8 \\
\hline Mkilwa & 4 & 1.7 & 2 & 3.7 & 1 & 1.3 & 1 & 1.9 & 0 & 0.0 \\
\hline Mzeru & 3 & 1.3 & 1 & 1.9 & 0 & 0.0 & 0 & 0.0 & 2 & 3.9 \\
\hline Mbunga & 4 & 1.7 & 0 & 0.0 & 0 & 0.0 & 0 & 0.0 & 4 & 7.8 \\
\hline Mbena & 2 & 0.8 & 0 & 0.0 & 0 & 0.0 & 1 & 1.9 & 1 & 2.0 \\
\hline Mzeguwa & 0 & 0.0 & 0 & 0.0 & 0 & 0.0 & 0 & 0.0 & 0 & 0.0 \\
\hline Mchilo & 8 & 3.4 & 0 & 0.0 & 3 & 3.8 & 3 & 5.8 & 2 & 3.9 \\
\hline Mnyani & 3 & 1.3 & 1 & 1.9 & 0 & 0.0 & 0 & 0.0 & 2 & 3.9 \\
\hline Mbuya & 0 & 0.0 & 0 & 0.0 & 0 & 0.0 & 0 & 0.0 & 0 & 0.0 \\
\hline Mtonga & 2 & 0.8 & 0 & 0.0 & 0 & 0.0 & 0 & 0.0 & 2 & 3.9 \\
\hline Mbangba & 0 & 0.0 & 0 & 0.0 & 0 & 0.0 & 0 & 0.0 & 0 & 0.0 \\
\hline Mkingwe & 0 & 0.0 & 0 & 0.0 & 0 & 0.0 & 0 & 0.0 & 0 & 0.0 \\
\hline Small clan total & 35 & 14.8 & 6 & 11.1 & 5 & 6.3 & 6 & 11.5 & 18 & 35.3 \\
\hline \multirow[t]{2}{*}{ Unknown } & 73 & 30.8 & 7 & 13.0 & 25 & 31.3 & 26 & 50.0 & 15 & 29.4 \\
\hline & 237 & 100.0 & 54 & 100.0 & 80 & 100.0 & 52 & 100.0 & 51 & 100.0 \\
\hline
\end{tabular}

${ }^{*}$ Households in this village often consist of nuclear families. Therefore, the heads of households are husbands who make up households, except for widow households.

\subsubsection{Maternal Clan Land Distribution}

Considering that about $60 \%$ of the sloped fields were derived from the maternal clan of either husband or wife, most village land was distributed based on the Luguru's traditional laws and customs, as it can be inferred that the land was held and passed down along the maternal line. Figure 4 shows the distribution of sloped fields used by members belonging to each of the three large clans and the remaining 12 small clans. The large clans cultivated a small amount of land in the village wards of Ludewa, Mvle and Klambazi and a larger amount in Kiseneke and Mungi. The sloped fields of the small clans were distributed mainly in Kiseneke and Mungi, and we found they were distributed at both high and low altitudes, similar to the lands of the large clans.

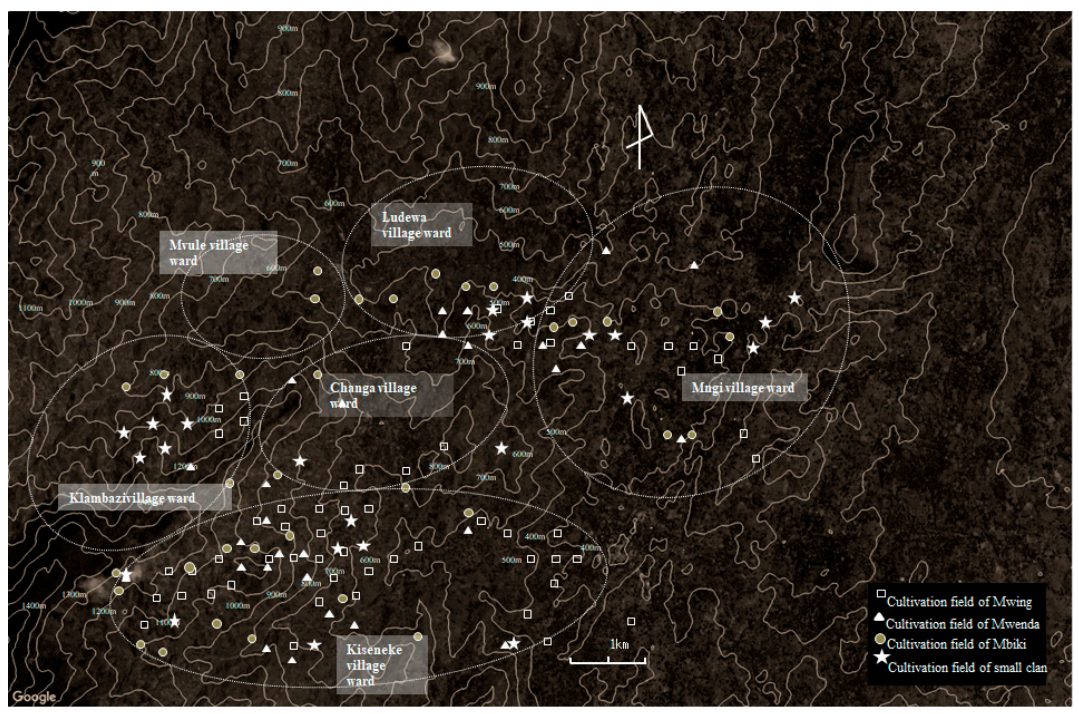

Figure 4. Distribution of large and small clan fields in Kiboguwa village. 


\subsection{Distribution of Lineage Land in Kiboguwa Village}

After determining how maternal clan land was distributed, we then focused on how lineage land, which is the unit of land ownership, was allotted. Lands managed by the head of the Kanoga lineage, which is part of the Mwing clan (Figure 5), were widely distributed in Kiboguwa, mainly in Kiseneke and Mungi. While there were large plots of land on the slope in Kiseneke, there were also many relatively small plots distributed in various elevation zones. Therefore, members of the Kanoga lineage could secure sloped fields at both high and low altitudes thanks to their lineage.

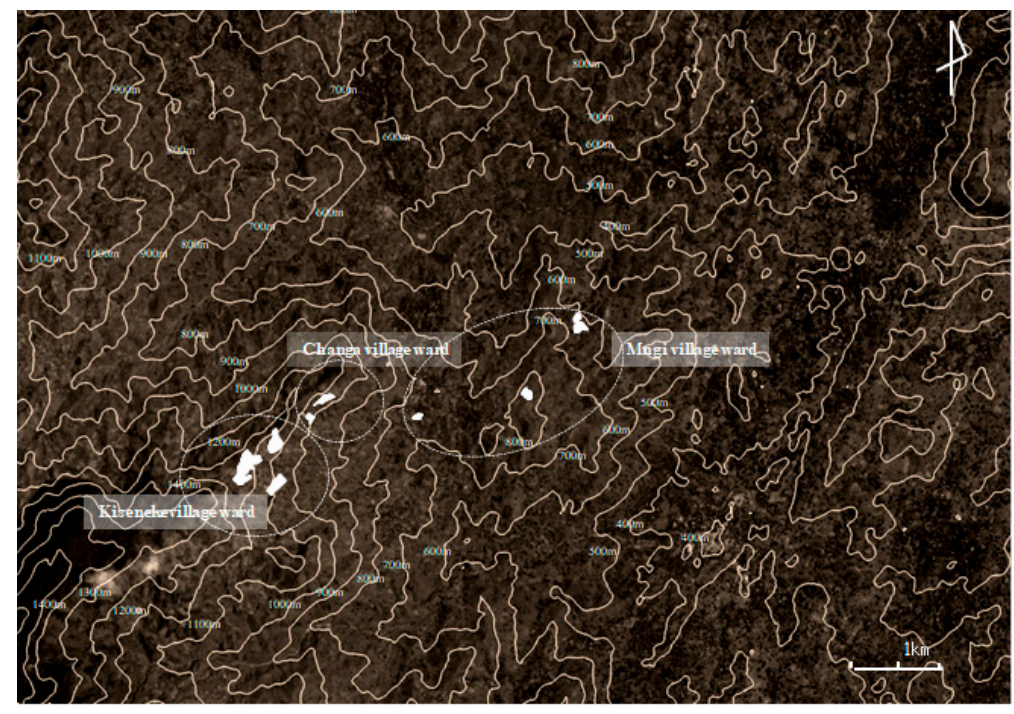

Figure 5. Distribution of land managed by the Kanoga lineage of the Mwing clan. The broken line shows the range of each village and the white plot inside shows the distribution of land managed by the head of Kanoga.

Thus, we found that maize, rice and cassava crops could all be cultivated by members of a particular maternal clan if the land-holding units (i.e., lineage lands) were located at various elevations.

\subsection{How to Obtain Sloped Fields from the Clan}

As described in the previous sections, the lands of both large and small clans, as well as the Kanoga lineage, were widely distributed in various elevation zones in the village. It turned out that sloped lands held by a particular lineage were distributed in both high and low areas. Therefore, in a household consisting of a couple, if the lineage land of either the husband or wife included land at both high and low altitudes, it would be possible to secure sloped fields for all three staple food crops. Thus, we investigated how a household belonging to one of the large clans (Mwing) and one belonging to a small clan would secure sloped fields distributed among different altitudes in the village.

\subsubsection{For Large Clans}

Of the 80 households we interviewed, 22 from the Mwing clan cultivated the land they secured in 2007 (Table 2). There were differences among Mwing households in land use. Of 22 households, $14(63.6 \%)$ mainly used land derived from the Mwing clan, but the other eight used non-Mwing land, which was secured from the wife's maternal clan or from the husband's or wife's paternal clan. Many households used three sloped fields to grow maize, rice, cassava and three other staple crops each year. Only seven households used sloped fields from the Mwing clan to cultivate the three crops. The other households used land from other clans and the other seven households included some that cultivated only 1 or 2 crops ( 4 households) or 1 crop ( 3 households) among the three crops and were members of the same clan. Although we found differences in land use, many households used the land derived from the lineage of either husband or wife, as well as sloped fields at different altitudes. 


\subsubsection{For Small Clans}

Table 3 shows how households, whose heads belonged to the 12 small clans, used sloped fields in 2007. Only five (26.3\%) out of 19 households used only the land derived from the small clans (i.e., land of the household head's mother or land of the maternal clan). Many other households cultivated land from the household head's paternal clan $(7,36.8 \%)$, who came from a different clan. Under traditional law, a child is considered a "lineage's grandchild." While the child can use the clan's land for as long as his/her father is alive, after the father's death, the land should be returned to the clan corresponding to its original tenure [17]. However, some members of the small clans listed in Table 3 continued to use the vast land of their father's maternal clan even after the father's death. This way of securing land is characteristic for heads of household belonging to a small clan. Thus, we could confirm that sloped fields are secured by means different from those used by large clan members.

Table 3. How sloped fields cultivated in 2007 were secured by households whose heads belonged to large clans and small clans, respectively.

\begin{tabular}{|c|c|c|c|c|c|c|c|c|c|c|c|c|}
\hline \multicolumn{7}{|c|}{ Large Clan * } & \multicolumn{6}{|c|}{ Small Clan ** } \\
\hline \multirow[t]{2}{*}{ Maize Field } & \multirow[b]{2}{*}{ (Field) } & \multirow[b]{2}{*}{$(\%)$} & \multicolumn{2}{|c|}{ Rice Field } & \multicolumn{2}{|c|}{ Cassava Field } & \multicolumn{2}{|c|}{ Maize Field } & \multicolumn{2}{|c|}{ Rice Field } & \multicolumn{2}{|c|}{ Cassava Field } \\
\hline & & & (Field) & $(\%)$ & (Field) & $(\%)$ & (Field) & $(\%)$ & (Field) & $(\%)$ & (Field) & $(\%)$ \\
\hline Maternal lineage of a household head & 10 & 41.7 & 13 & 54.2 & 10 & 41.7 & 6 & 30.0 & 8 & 33.333 & 6 & 26.1 \\
\hline Maternal lineage of wife & 4 & 16.7 & 4 & 16.7 & 2 & 8.3 & 4 & 20.0 & 5 & 20.8 & 1 & 4.3 \\
\hline Household head's father & 1 & 4.2 & 1 & 4.2 & 0 & 0.0 & 2 & 10.0 & 6 & 25.0 & 5 & 21.7 \\
\hline Wife's father & 2 & 8.3 & 1 & 4.2 & 0 & 0.0 & 0 & 0.0 & 2 & 8.3 & 0 & 0.0 \\
\hline Leased & 3 & 12.5 & 2 & 8.3 & 2 & 8.3 & 2 & 10.0 & 2 & 8.3 & 0 & 0.0 \\
\hline Purchased & 0 & 0.0 & 1 & 4.2 & 0 & 0.0 & 0 & 0.0 & 1 & 4.2 & 0 & 0.0 \\
\hline Government & 0 & 0.0 & & 0.0 & 1 & 4.2 & 1 & 5.0 & 0 & 0.0 & 1 & 4.3 \\
\hline No fields & 4 & 16.7 & 0 & 0.0 & 4 & 16.7 & 5 & 25.0 & 0 & 0.0 & 5 & 21.7 \\
\hline \multirow[t]{2}{*}{ Unknown } & 0 & 0.0 & 2 & 8.3 & 5 & 20.8 & 0 & 0.0 & 0 & 0.0 & 5 & 21.7 \\
\hline & 24 & 100.0 & 24 & 100.0 & 24 & 100.0 & 20 & 100.0 & 24 & 100.0 & 23 & 100.0 \\
\hline
\end{tabular}

* sloped fields cultivated by 22 households whose heads belong to Mwing clan. ** sloped fields cultivated by 19 households from small clans (4 in Mtonga, 3 in Mzeru, 3 in Mbena, 3 in Mbunga, 2 in Mlari, 2 in Mtsuma, 1 in Mshrom, 1 in Muchiro).

\subsection{Residence Forms}

Sixty percent of households constituting married couples used sloped fields derived from the mother's clan. However, access to the clan's land differed depending on the household. Even in the case of households whose heads belonged to a large clan, more than one-third of these households also cultivated land from the wife's maternal or paternal side. Many households whose head belonged to a small clan tended to used land derived from the husband's paternal clan. In addition, even some households whose head belonged to small clans also used land derived from the wife's paternal clan to secure sloped fields for cultivating staple food crops. However, as few as $20 \%$ of households mainly used purchased or leased land and somehow managed to secure land from either the husband's or wife's parents' clan to cultivate maize, rice and cassava at different altitudes.

Although 70\% of households cultivated crops on the sloped fields in Kiboguwa, if a household included a spouse from a different village, that household had the possibility to also use fields belonging to the spouse's village. In such cases, it is highly probable that securing a sloped field in Kiboguwa would be difficult. Therefore, each household's residence form, which described virilocal, uxorilocal or another type of residence, was surveyed.

First, we asked respondents how they obtained their place of residence. Luguru households often comprise a couple and their unmarried children, and in many cases, sloped fields are obtained through the mother's clan, as mentioned earlier. Virilocal residence, which refers to a couple living on land belonging to the husband's clan, is disadvantageous in this society in terms of securing the children's right to use the sloped field. We found that $37(46.3 \%)$ out of 80 households resided on land derived from either the paternal or maternal clan of either the wife or husband. In addition, 19 (23.8\%) of these households corresponded to virilocal residence and $18(22.5 \%)$ to uxorilocal residence. This means that in more than $20 \%$ of the households, the women left the land of their mother's clan to live on land of their husband's clan, which their children will not have the right to use. Additionally, the second 
most common form of obtaining land was distribution from the government (32 households, $40.0 \%$ ). In Tanzania, as part of the socialist policies implemented from the 1960s to early 1970s, the government constructed Ujamaa villages to support the livelihoods of dispersed people and increase agricultural productivity [20,21]. After 1971, a semi-compulsory migration operation (Operation Vijijini) for mass resettlement began nationwide. In Kiboguwa in 1974 [20,21], the Tanzanian government confiscated the land of a specific clan (more precisely, a lineage) and redistributed the lots, including to households not belonging to that clan. In 2007, 32 households or about $40 \%$ of the 80 households surveyed, lived on land that had been granted by the government at the time of settlement or that they had inherited through lineage [14].

It was inferred from conversations with village elders that the government had confiscated much land, but the traditional landholding mechanism had been maintained for most of the sloped fields. In addition, since the mass resettlement was confined to village units, the semi-compulsory migration operation did not force residents to move beyond the village borders. Thus, the original villagers could use the village's sloped fields to create their residences. Therefore, village members remained the same before and after the migration operation.

\subsection{Marriage Practices to Prevent the Use of Sloped Fields by Cultivators from Other Villages}

We observed similar levels of both virilocal and uxorilocal residences, meaning the number of virilocal residence households was not inconsequential. Considering the percentage of those with virilocal residence $(23.8 \%)$, these women and their families live on land derived from the husband's parents. While this is not the women's birth village, they can still use land from their mothers, which is in Kiboguwa. In addition, it is easier to determine if women who are married to someone from another village are cultivating a sloped field in Kiboguwa. However, very few people who live outside Kiboguwa go there to cultivate sloped fields; most sloped fields in the village are cultivated by its residents.

In fact, marriage customs are deeply related to land use. Of the 254 households confirmed by satellite imaging, we obtained information for 225 related to the origins of the household members. In 135 households $(60.0 \%)$, the husband was from the current residential area (Table 4$)$. In addition, regarding the origins of the wives of these households, a high percentage $(105,77.8 \%)$ were from Kiboguwa. More than $70 \%$ of households in Kiboguwa were intra-village ward marriages: 22 of 24 in Mungi (91.7\%); 26 of 35 in Ludewa (74.3\%); and 29 of 46 in Kiseneke (63.0\%). Even in Changa, which had the lowest percentage of intra-village marriages (14 (46.7\%) out of 30 households), it was still nearly half. Thus, due to the tendency for people to marry within the same village ward, the sloped fields are inherited only within the village.

Table 4. Place of birth of villagers in 4 village wards and ratios of intra- and inter-village ward marriages.

\begin{tabular}{|c|c|c|c|c|c|c|c|c|c|c|}
\hline \multicolumn{11}{|c|}{ Birthplace of Household Head * } \\
\hline & \multicolumn{2}{|c|}{ Four Village Wards } & \multicolumn{2}{|c|}{ Kiseneke } & \multicolumn{2}{|c|}{ Changa } & \multicolumn{2}{|c|}{ Ludewa } & \multicolumn{2}{|c|}{ Mungi } \\
\hline & Total & $(\%)$ & (People) & $(\%)$ & (People) & $(\%)$ & (People) & $(\%)$ & (People) & $(\%)$ \\
\hline Number of surveyed households * & 225 & & 63 & & 59 & & 52 & & 51 & \\
\hline $\begin{array}{l}\text { Household head (husband) is from } \\
\text { current residence }\end{array}$ & 135 & 60.0 & 46 & 73.0 & 30 & 50.8 & 35 & 67.3 & 24 & 47.1 \\
\hline \multicolumn{11}{|c|}{ Birthplace of spouse } \\
\hline Kiseneke & 35 & 25.9 & 29 & 63.0 & 5 & 16.7 & 1 & 2.9 & 0 & 0.0 \\
\hline Changa & 15 & 11.1 & 1 & 2.2 & 14 & 46.7 & 0 & 0.0 & 0 & 0.0 \\
\hline Ludewa & 26 & 19.3 & 2 & 4.3 & 2 & 6.7 & 22 & 62.9 & 0 & 0.0 \\
\hline Mungi & 24 & 17.8 & 0 & 0.0 & 1 & 3.3 & 1 & 2.9 & 22 & 91.7 \\
\hline Other village wards & 5 & 3.7 & 1 & 2.2 & 1 & 3.3 & 2 & 5.7 & 1 & 4.2 \\
\hline Other villages & 28 & 20.7 & 11 & 23.9 & 7 & 23.3 & 9 & 25.7 & 1 & 4.2 \\
\hline Unknown & 2 & 1.5 & 2 & 4.3 & 0 & 0.0 & 0 & 0.0 & 0 & 0.0 \\
\hline Intra-village ward marriage & 87 & 64.4 & 29 & 63.0 & 14 & 46.7 & 22 & 62.9 & 22 & 91.7 \\
\hline Inter-village marriage & 105 & 77.8 & 33 & 71.7 & 23 & 76.7 & 26 & 74.3 & 23 & 95.8 \\
\hline Marriage outside the village $* *$ & 28 & 20.7 & 11 & 23.9 & 7 & 23.3 & 9 & 25.7 & 1 & 4.2 \\
\hline
\end{tabular}

* of 254 households confirmed by satellite imaging, the number of households whose members' hometown information was obtained by informants. ${ }^{* *}$ - either husband or wife is from a village other than Kiboguwa. 


\section{Conclusions}

On the sloped fields of Kiboguwa village, a certain cropping pattern of maize, rice and cassava was observed at different altitudes and during certain seasons for each crop. The village's sloped fields were cultivated mainly by village residents. Approximately $70 \%$ of the households were involved in maintaining the cropping system, which incorporates the three staple crops, while using the sloped fields distributed at different altitudes.

Multiple factors, including certain social mechanisms, were used to maintain the cropping system. One of these mechanisms was the land tenure custom based on lineage. Another mechanism was the land itself, which included both high and low altitude terrain. The wide distribution of elevations made it possible for households to cultivate maize, rice and cassava with access to only a single lineage sloped field. However, many households could not secure the sloped fields on land derived from the household head's maternal lineage, which meant that land derived from the wife's maternal clan was often used. Although there were many cases in which sloped fields were secured on land derived from the maternal clan, farmland was derived from the paternal clan of either husband or wife in approximately $20 \%$ of households. Further, in cases where the father had died, the land was still being used by the children. Such cases may mean that landholding practices centered on the maternal line are changing, but there were few cases where sloped fields were secured by lease or purchase. Considering this, we can determine that the clan-centered landholding system continues to influence Kiboguwa's farming system.

The incidence of virilocal and uxorilocal residence was similar; thus, considering only the mechanism of land retention from the maternal clan, the sloped fields outside the village were being farmed by village residents. It was rare for people living outside Kiboguwa to use the sloped fields inside the village. Nearly $80 \%$ of marriages were inter-village, which made it possible to maintain the cropping system. The village's high marriage rate is considered closely related to a Luguru marriage custom called "cross-cousin marriage," which was developed to prevent excessive dispersion of lineage-owned sloped fields [17,22]. Although this survey did not clarify the number of cross-cousin marriages in the village, it is clear from the surveys that, for example, an uncle would prefer his son to marry his niece who does not share his maternal lineage. This cultural device has been considered to affect the rate of marriage. In rural areas of Africa, crop productivity is not high to begin with, and there is a need for assistance to increase both population and productivity [23-25]. Even in Kiboguwa, the crop productivity was low, and behaviors were observed, such as selling a commercial crop like bananas and purchasing and supplementing staple foods $[13,26]$. Therefore, it can be said that the support itself is necessary, even at this survey site.

The cropping system used to cultivate staple food crops on the mountain slopes in Kiboguwa is simple. Cultivation performed in the same cropping order as this survey site is common in other mountainous regions $[27,28]$. This system seems easy to understand from the relationship between cultivation characteristics and ecological environment, which differs depending on altitude. However, this cropping system was established and maintained because of social factors such as marital structure, in addition to the customs of land tenure centered on maternal lineage. In addition, differences in clan types and households were found in how arable land is secured. Current agricultural technical assistance tends to focus on technology provision and development and social factors tend to be analyzed mainly from an economic perspective to determine the content and method of assistance [29]. Rural economies and agriculture in developing countries that are not modernized are strongly influenced by cultural elements of the local communities. These communities are formed by social groups centered on undifferentiated kinships that are related by blood and are unique to the region [30]. Even for the purpose of improving household productivity and profitability, support should not be selected that creates disparities and conflicts and does not match the cultural elements unique to the target community [31-33]. Researchers or practitioners engaged in agricultural technical assistance have an ethical responsibility as outsiders in a position that can bring about change in a community. We must recognize the possibilities and the need to develop a better understanding of the values and 
unique characteristics of these communities that require assistance [34,35]. To that end, in addition to conducting a quantitative survey using questionnaires, we also collected qualitative information on local agriculture and society through the long-term stay survey method implemented in this study [36]. Furthermore, regarding the direction of assistance, researchers should strive to understand the region's uniqueness as much as possible and to provide support that raises the standard of living of the community without breaking the relationships and connections of farmers in the region [37].

Author Contributions: Conceptualization, Y.Y.; methodology, Y.Y.; software, Y.Y.; validation, Y.Y.; formal analysis, Y.Y.; investigation, Y.Y.; resources, Y.Y.; data curation, Y.Y.; writing-original draft preparation, Y.Y.; writing-review and editing, Y.Y.; visualization, Y.Y.; supervision, K.I.; project administration, X.X.; funding acquisition, Y.Y. All authors have read and agreed to the published version of the manuscript.

Funding: This study was supported by a Grant-in-Aid for Scientific Research (16101009).

Acknowledgments: We would like to thank Kana Yamamoto of Kyoto University and Shigehiro Sasaki of Nagoya University, who provided many useful suggestions for this article. I would like to thank you for your comments.

Conflicts of Interest: The authors declare no conflict of interest.

\section{References}

1. Satoshi, T. African peasant economy as seen from moral economy theory: A comparative study of peasant theories on Africa and Southeast Asia. Afr. Stud. 2002, 70, 51-62. (In Japanese)

2. Norton, G.W.; Alwang, J.; Masters, W.A. Economics of Agricultural Development: World Food Systems and Resource Use; Routledge: New York, NY, USA, 2015.

3. Soda, O. History of Modern Agricultural Thought for 21st Century Agriculture; Iwanami Shoten: Tokyo, Japan, 2013; p. 236. (In Japanese)

4. Shigeta, M. Possibility of sustainable intensive agriculture in Africa: A case study of conventional agriculture in the southwestern part of Ethiopia based on Ensete. In The World of African Farmer: Its Nativeness and Transformation; Kakeya, M., Ed.; Kyoto University Press: Kyoto, Japan, 2002; pp. 163-195. (In Japanese)

5. Irie, K. Tropical agriculture and international cooperation. In Introduction of Tropical Agriculture; Ehara, H., Higuchi, H., Eds.; Bifuukan: Tokyo, Japan, 2019; pp. 232-242. (In Japanese)

6. Nishimura, Y. Rural agriculture/rural development and technology development/technology transfer. In Introduction to International Development Studies: Interdisciplinary Construction of Development Studies; Otsubo, S., Kimura, H., Ito, S., Eds.; Keiso Shobo: Tokyo, Japan, 2007; pp. 334-343. (In Japanese)

7. Hayami, Y.; Kikuchi, M. A Rice Village Saga: Three Decades of Green Revolution in the Philippines; Macmillan Press: London, UK, 2000.

8. Kakeya, M. African area studies and international cooperative activities: Indigenous agriculture and sustainable rural development. Area Study Asia Afr. 2001, 1, 68-80. (In Japanese)

9. Saito, K.A.; Weidemann, C.J. Agricultural Extension for Women Farmers in Africa; The World Bank: Washington, DC, USA, 1990; p. 54.

10. Nishimura, Y. Crop. System Technology in Tropical Asia; Tsukuba Publishing: Tokyo, Japan, 2009; p. 175.

11. Adhikari, C.; Adhikari, B.; Rajbhandari, N.P.; Hooper, M.; Upreti, H.K.; Gyawali, B.K.; Rajbhandari, N.K.; Hobbs, P.R. Wheat and Rice in the Mid-Hills of Nepal: A Benchmark Report on Farm. Resources and Production Practices in Kavre District; CIMMYT and NARC: Kathmandu, Nepal, 1999; p. 26.

12. De Bauw, P.; VanAsten, P.; Jassogne, L.; Merckx, R. Soil fertility gradients and production constraints for coffee and banana on volcanic mountain slopes in the East African Rift: A case study of Mt. Elgon. Agric. Ecosyst. Environ. 2016, 231, 166-175. [CrossRef]

13. Yamane, Y.; Jagath, K.; Ito, K. Agricultural production and food consumption of mountain farmers in Tanzania: A case study of Kiboguwa village in Uluguru Mountains. Agric. Food Secur. 2018, 7, 54. [CrossRef]

14. Yamane, Y.; Jagath, K.; Ito, K. Diversity of cropping patterns and factors affecting homegarden cultivation in Kiboguwa on the Eastern slopes of the Uluguru Mountains in Tanzania. Agriculture 2018, 8, 141. [CrossRef]

15. Hayashi, H. Development and expansion of agricultural forms. In Introduction of Tropical Agriculture; Higuchi, H., Ehara, H., Eds.; Baifuukan: Tokyo, Japan, 2019; pp. 37-56. (In Japanese)

16. Beidelman, T.O. The Matrilineal Peoples of Eastern Tanzania. East. Central Africa Part. 16; International African Institute: London, UK, 1967; pp. 26-34. 
17. Young, R.; Fosbrooke, H. Smoke in the Hills: Political Tension in the Morogoro District of Tanganyika; Northwestern University Press: Evanston, IL, USA, 1960; p. 212.

18. Brain, J.L. The Uluguru land usage scheme: Success and failure. J. Dev. Areas 1980, 14, 175-190.

19. Van Donge, J.K. The arbitrary state in the Uluguru Mountains: Legal arenas and land disputes in Tanzania. J. Mod. Afr. Stud. 1993, 31, 431-448. [CrossRef]

20. Hyden, G. Beyond Ujamaa in Tanzania: Underdevelopment and an Uncaptured Peasantry; University of California Press: Berkeley, CA, USA, 1980; p. 270.

21. Hiromi, A. Tanzania "Lands 1999 Village Land Law" land ownership: “Comprehensive mini-corporate structure" and its comparative study. Int. Dev. Res. Forum 2004, 25, 21-38. (In Japanese)

22. McVicar, T. Sibs, privileged familiarity, and cross-cousin marriage among the Waluguru. Primit. Man 1935, 8 , 57-67. [CrossRef]

23. Bassett, T.J.; Crummey, D.E. Land in African Agrarian Systems; University of Wisconsin Press: Madison, WI, USA, 1993; p. 427.

24. Misana, S.B.; Majule, A.E.; Lyaruu, H.V. Linkages between Changes in Land Use Biodiversity and Land Degradation on the Slopes of Mount Kilimanjaro, Tanzania. LUCID Working Paper No. 38; International Livestock Research Institute: Nairobi, Kenya, 2003.

25. Reyes, T.; Quiroz, R.; Msikula, S. Socio-economic comparison between traditional and improved cultivation methods in agroforestry systems, East Usambara Mountains, Tanzania. Environ. Manag. 2005, 36, 682-690. [CrossRef] [PubMed]

26. Yamane, Y.; Higuchi, H. Subsistence strategy of small farmers observed in planting of commercial crops in the homestead of the mountains of rural Tanzania. A case study of Kiboguwa Village on the Eastern Slopes of Uruguru Mountain in Tanzania. J. Agric. Dev. Stud. 2016, 27, 1-12. (In Japanese)

27. Yamamoto, N. Potato and the Inca Empire: Plants that Gave Birth to Civilization; The University of Tokyo Press: Tokyo, Japan, 2004; p. 217. (In Japanese)

28. Yamamoto, N.; Motoe, A.; Fujikura, Y. Crops, livestock and forests. In Himalayan Environmental Magazine: Nature in Mountain Areas and the World of Sherpa; Yamamoto, N., Inamori, T., Eds.; Yasaka Shobo: Tokyo, Japan, 2000; pp. 100-118. (In Japanese)

29. Suzuki, S. Agricultural Diffusion in Developing Countries and its Evaluation; Tokyo University of Agriculture Publishing: Tokyo, Japan, 2009; p. 165.

30. Palmer, R. Contested Land in Southern and Eastern Africa: A Literature Survey; Oxfam Working Papers Series; Oxfam: Oxford, UK, 1997; p. 310.

31. Yamane, Y. Who needs support? A case study of agricultural technical support in Kenya. J. Agric. Dev. Stud. 2018, 29, 2-13. (In Japanese)

32. Ito, N. Mechanism and function of food distribution in rural Africa-Analysis of rice consumption process of Kenyan irrigation project area. Res. Agric. Forest. Fish. Pol. 2017, 27, 1-24. (In Japanese)

33. Anderson, R.B.; Dana, L.P.; Dana, T.E. Indigenous land rights, entrepreneurship, and economic development in Canada: "Opting in" to the global economy. J. World Bus. 2006, 41, 45-55. [CrossRef]

34. Popkin, S.L. The Rational Peasant: The Political Economy of Rural Society in Vietnam; University of California Press: Berkeley, CA, USA, 1979; p. 202.

35. Chambers, R. Rural Appraisal: Rapid, Relaxed and Participatory; IDC: High Point, NC, USA, 1992; p. 68. Available online: https://opendocs.ids.ac.uk/opendocs/bitstream/handle/20.500.12413/774/Dp311.pdf?sequence=1\& isAllowed=y (accessed on 1 January 2020).

36. Maxwell, J.A. Qualitative Research Design: An. Interactive Approach (Applied Social Research Methods); SAGE Publications: Thousand Oaks, CA, USA, 2005; pp. 87-121.

37. Lasker, R.D.; Weiss, E.S. Broadening participation in community problem solving: A multidisciplinary model to support collaborative practice and research. J. Urban Health 2003, 80, 14-47. [CrossRef] [PubMed]

(C) 2020 by the authors. Licensee MDPI, Basel, Switzerland. This article is an open access article distributed under the terms and conditions of the Creative Commons Attribution (CC BY) license (http://creativecommons.org/licenses/by/4.0/). 